Article

\title{
Agricultural Irrigation Water Use in a Closed Basin and the Impacts on Water Productivity: The Case of the Guadalquivir River Basin (Southern Spain)
}

\author{
Alfonso Expósito ${ }^{1, *}$ and Julio Berbel ${ }^{2}$ \\ 1 Department of Economic Analysis, University of Sevilla, 41018 Sevilla, Spain \\ 2 Department of Agricultural Economics, University of Cordoba, 14014 Cordoba, Spain; berbel@uco.es \\ * Correspondence: aexposito@us.es; Tel.: +34-656-626953
}

Academic Editor: Davide Viaggi

Received: 15 November 2016; Accepted: 13 February 2017; Published: 20 February 2017

\begin{abstract}
This paper analyses the agricultural irrigation water use in a closed basin and the impacts on water productivity, and examines how they have affected the 'closure' process of the Guadalquivir river basin observed in recent decades. Following a period of expansion in irrigation, an administrative moratorium was declared on new irrigated areas in 2005. Since then, the main policy measure has been aimed at the modernisation of irrigated agriculture and the implementation of water conservation technologies. The analysis carried out in this paper shows a significant increase in mean irrigation water productivity in the pre-moratorium period (1989-2005), driven by the creation of new irrigated areas devoted to high value crops and with a dominant use of deficit irrigation strategies, while a second phase (2005-2012) is characterised by slower growth in terms of the mean productivity of irrigation water, primarily as a result of a significant reduction in water use per area. Findings show that productivity gains seem to have reached a ceiling in this river basin, since technological innovations (such as new crops, deficit irrigation, and water-saving and conservation technologies) have reached the limits of their capacity to create new value.
\end{abstract}

Keywords: irrigation water productivity; agricultural water use; basin closure; water policy

\section{Introduction}

Irrigated agriculture occupies about $15 \%$ of the total cultivated area in Spain but is responsible for $60 \%$ of the total value of agricultural production; the average production per hectare of irrigated crops is 6.5 times greater than that of rain-fed agriculture. Irrigation plays a more important role in southern Spain, where the Guadalquivir river basin (RB) is located; this basin is subject to typical Mediterranean intra- and inter-seasonal rainfall variability and increasing pressures on scarce water resources.

The Guadalquivir RB, which is representative of Mediterranean agriculture, has undergone intense transformation in the last 50 years, characterised by a significant growth of irrigated areas, a progressive change in the composition of crops and widespread implementation of water-saving and conservation technologies (WCTs). Farmers must adapt to water scarcity and a continued decline in farm incomes (falling 1.1\% annually since the beginning of the 90s, according to Spanish Ministry of Agriculture and Environment (MARM) [1], which attributes this decrease to the increasing cost of inputs and lower commodity prices), and they have reacted by prioritising crops with greater value added per hectare and higher productivity per water input.

Moreover, farmers facing growing resource scarcity and increasing water costs have responded by using the resource more efficiently; consequently, significant investments (public and private) have been made over the last decades to improve water-use efficiency as part of an initiative to modernise irrigated areas in southern Spain. 
The aim of this paper is to analyse the changes in agricultural water use patterns, the irrigation modernisation process, and the impacts on irrigation water productivity, which have characterised the 'closure' process of the Guadalquivir RB observed in recent decades. Basin closure is an anthropogenic process and is manifested at societal as well as ecosystem levels [2]. The main changes observed in the Guadalquivir RB in recent decades have been (1) significant growth in the demand for irrigation water (2) increasing economic productivity associated with water, and (3) intense process of modernisation of irrigation techniques (WCTs) used in the basin.

To this end, the rest of this paper is organised as follows. The next section introduces the theoretical framework regarding mature water economies and basin closure. The third section briefly describes the main changes that have taken place in Guadalquivir basin with respect to: (a) the extent of the irrigated area; (b) water consumption; and (c) modernisation of irrigation schemes. It also examines the effects of these changes in the basin over the last two decades. The fourth section outlines the model for understanding the process of basin closure, a process characterised by growing pressures on water resources mainly linked to agricultural water demand in a context of water scarcity, and the consequences of increasing economic productivity of irrigation water. A brief discussion of the findings is offered in the fifth section, and the paper ends with some concluding remarks.

\section{Mature Water Economies and Basin Closure}

According to Randall [3], in the 1980s the Australian water economy entered a 'mature phase' characterised by: (1) inelastic water supply with increasing marginal supply costs (aquifers were already heavily exploited, the best dam locations had been taken and other rivers were protected); (2) high and growing demand (with increasing conflicts among water users); (3) an aging infrastructure which required expensive renovation; (4) a context of increasing negative externalities and (5) a rising social cost of subsidising water use. Randall's framework for describing the mature phase of a water economy has been applied to other countries, such as Spain, where the radical new 'Water Law' was approved in 1985. This law reinforced the public nature of all water resources, ensuring that they are used according to prior allocation of water rights, and Randall's description of the situation in Australia played a key role in the ideological debate surrounding the related Spanish legislation.

Randall's analysis was developed in the field of public policy and agricultural and environmental economics; accordingly, his framework is often used in this field. The level of analysis therefore focuses on national policy and the instruments recommended are mainly economic in nature (i.e., water pricing or markets).

A different approach comes from the fields of hydrology and agronomy, where the concept of 'basin closure' has been widely used since a 2006 seminar organised by the Stockholm International Water Institute (SIWI) and the Consultative Group on International Agricultural Research (CGIAR), held to discuss the issue of closed basins. In this seminar, the symptoms of a river basin closure and its social and ecological impacts were analysed, as well as the necessary adaptation processes required to achieve a 'soft landing'. Evidence of basin overbuilding and basin closure can be found in many basins, including those of the Jordan River, the Krishna River, the Lerma-Chapala River, the Murray-Darling River, the Colorado River, the Indus River in India and Pakistan, the Yellow River and many others. In this regard, basin closure is defined as an anthropogenic process and the term has been used to describe the situation in a number of basins and aquifers [2]. An example of this analytical framework can be found in Comair et al. [4] and Venot et al. [5], which describe how population growth and increased agricultural demand are contributing to the closure of the Jordan basin.

To the best of our knowledge, the concepts of 'mature water economy' and 'basin closure' have not been fully integrated in the existing literature and they are rarely included together in the same study. An explanation for this may lie in the different levels of analysis of the two analytical frameworks. Randall's 'mature water phase' is defined at national level, with economic and normative instruments defined at this level. Conversely, basin closure is defined in hydrological terms, and economic 
instruments may be used when the basin belongs mainly to a single country. Nevertheless, as most of the basins listed above are international, finding sustainable solutions entails greater complexity.

We argue that Randall's 'mature phase', which is characterised by inelastic water supply with increasing marginal costs, eventually reaches a point where resource supply augmentation is no longer feasible and the inelastic water supply becomes vertical. Thus, the question arises as to how to allocate scarce resources in a basin or aquifer that is already 'overallocated'. Overallocation is a common problem in water-scarce regions. A recent study by Grantham and Viers [6] estimates that overall allocation of water resources in California is five times the average supply of renewable water resources, with some rivers reaching overallocation levels of up to $1000 \%$.

We believe that the framework of a mature water economy phase is complementary to the hydrological and ecosystem concept of a 'closed basin', as the solutions to this problem should consider the local situation (natural, social and technical constraints at aquifer or subbasin level), as well as the national policy institutions (the legal framework for managing water resources). Moreover, basin closure status may be seen as a phase beyond a 'mature water economy', indicating the onset of an 'emergency' phase.

In this research paper, we present a case study of a closed basin that has reached the limit where no additional water sources are foreseen, and in which economic instruments (reallocation, volumetric pricing, water rights markets, etc.) and technical strategies (water saving, improved water productivity and water efficiency) have already been widely implemented.

\section{Characterisation of the Guadalquivir RB, Closure Process and Main Responses}

The Guadalquivir RB, which is representative of the Mediterranean region, contains $23 \%$ of the total irrigated area in Spain [7]. The competitiveness of its agriculture, with a focus on high value crops in a context of water scarcity, explains the remarkable expansion in irrigated areas and modernisation of irrigation systems in recent decades, to the point where there are now more than 850,000 hectares of irrigated land. The Guadalquivir is the longest river in southern Spain, with a length of about $650 \mathrm{~km}$ and a basin extension of over $57,527 \mathrm{~km}^{2}$. Land in the basin is divided between forests $(49.1 \%)$, agriculture $(47.2 \%)$, urban areas $(1.9 \%)$ and wetlands $(1.8 \%)$. The basin has a Mediterranean climate with an average rainfall of $573 \mathrm{~mm}$, occasional periods of prolonged drought, and an average annual temperature of $16.8^{\circ} \mathrm{C}$.

Irrigation in Spain has a long and complex history and the analysis of national-scale data reveals no clear patterns of change as the present agricultural systems are very heterogeneous. The north has a continental climate and farmers grow commodity crops (i.e., maize, sugar beet), whereas in the southeast farmers face extremely arid conditions and tend to specialise in out-of-season intensive fruit and vegetable cultivation. Agriculture in the Guadalquivir RB centers on high value crops, which represents a mid-point between the extremely intensive system in the southeast and the low-productivity irrigation in northern basins.

The current reservoir capacity in the Guadalquivir RB is $8600 \mathrm{hm}^{3}$ and the average water use in the basin amounts to about $3800 \mathrm{hm}^{3}$ per year [8], of which about $3400 \mathrm{hm}^{3}$ goes to meet the demand of irrigated agriculture (which represents $85 \%$ of the total water demand in the basin). The Guadalquivir Hydrological Plans for both the first period under analysis (2010-2015) and the current one (2015-2021), declare that the level of consumption has reached its maximum and that no significant supply increases are foreseen in the years to come. Against this backdrop, demand management has become the only available tool to manage water demand in the different socio-economic sectors, including agriculture [9]. Thus, the use of more efficient irrigation techniques plays a key role in achieving water-saving objectives, especially in a context of continuing pressure to increase irrigated areas, despite the explicit administrative moratorium on any further transformation of rain-fed lands into irrigated farmland.

The most relevant change in recent decades has been the continuing transformation of rain-fed olive groves to groves irrigated by drip systems. According to the Spanish Ministry of Agriculture [7], the average value of olive production in the Guadalquivir RB is $1300 \mathrm{EUR} /$ ha for rain-fed olives and 
2500 EUR/ha for irrigated olives. Irrigated olive crops make up $52 \%$ of the basin irrigated area $(46 \%$ in $2005)$, followed by extensive crops (30\%). The latter includes winter cereals $(14 \%)$, sunflower $(6 \%)$, cotton $(6 \%)$ and corn $(3 \%)$. Other important crops in the basin are fruits, which cover $7 \%$ of the total irrigated area, and rice, which represents $4 \%$.

As shown in Figure 1, the irrigated area in the Guadalquivir basin has increased continuously over the past two decades, mainly through the abovementioned conversion of rain-fed olive groves into irrigated groves. The rate of conversion from rain-fed to irrigated farmland reached markedly high levels in the second half of the 1990s, when the extreme drought that occurred between 1992 and 1994 drove many rain-fed farms (especially those with olive groves) to convert to irrigation systems by means of private initiatives. In 2005, an administrative moratorium was declared on new irrigated areas in the main subbasin (comprising $90 \%$ of the irrigated area), with marginal increases in irrigated areas still allowed in the remaining $10 \%$ of the basin. The impact of this moratorium is reflected in in the reduction of the average annual growth rate of irrigated areas, from $9 \%$ in the period $1989-2005$ to $0.8 \%$ in the subsequent period.

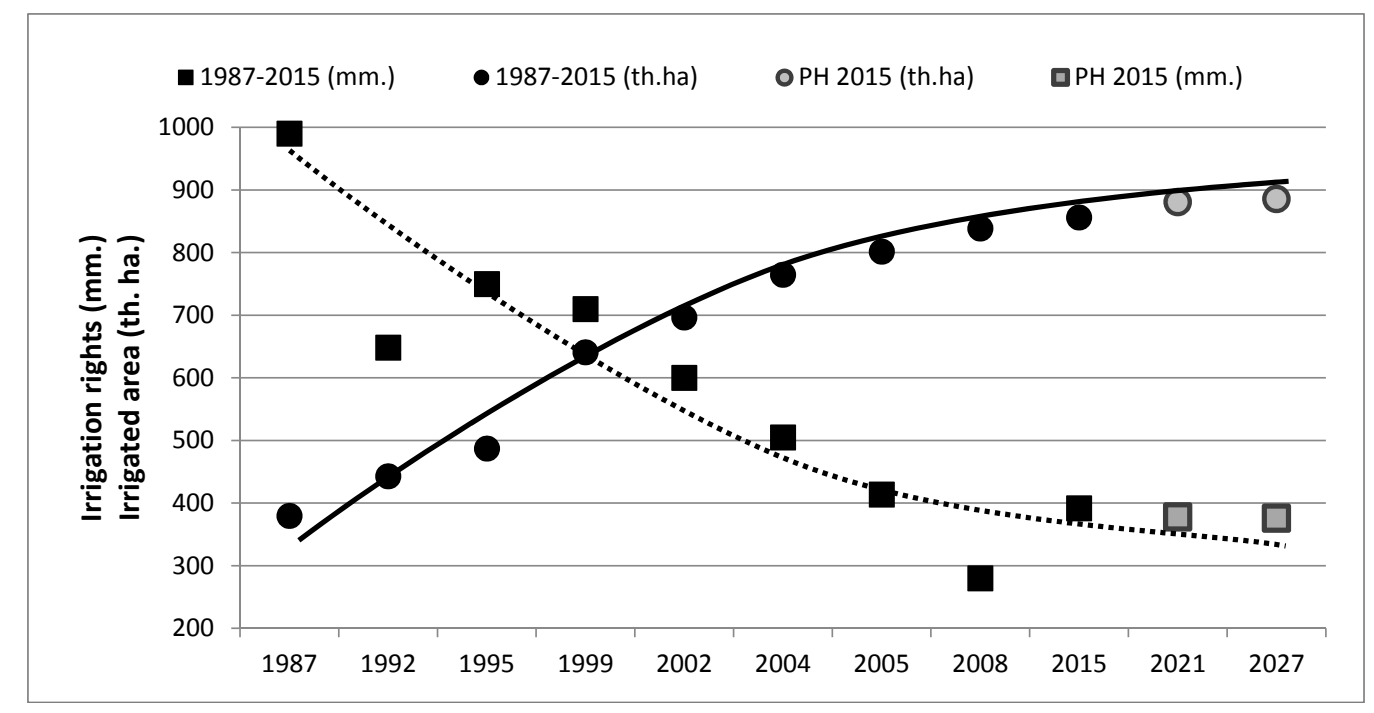

Figure 1. Average irrigation rights and irrigated area. Source: Own elaboration using data from the Guadalquivir Basin Authority and Irrigation Inventories. Adjusted polynomial trend lines are shown in order to describe the trajectory followed by irrigated area (solid trend line) and by average irrigation rights (dotted trend line).

Figure 1 illustrates the reduction in the average water rights for irrigation $\left(\mathrm{m}^{3}\right.$ per ha) resulting from the depletion of water resources in the basin, falling from an annual water allotment of $9800 \mathrm{~m}^{3}$ per hectare in 1987 to $3400 \mathrm{~m}^{3}$ per hectare in 2012 [8]. Farmers have adapted to this reduction in water rights by modernising, investing in WCTs and using deficit irrigation (DI) strategies. The modernisation process of irrigation techniques has played a decisive role in the significant increase in irrigation water productivity in recent decades. The fact that the irrigated area in the basin doubled at the same time as a drastic reduction took place in the average irrigation rights per hectare can only be explained by the major investments made in WCTs. In this context, the greater water-use efficiency as an expected effect of irrigation modernisation, along with farmers' increasing commitment to crops with a more efficient water consumption and greater capacity to generate high agricultural yields (i.e., olive groves), have helped the basin to reach high efficiency levels in the use of the scarce water resources available.

The modernisation of irrigated agriculture in the Guadalquivir RB in recent years has been promoted by the regional government through the Andalusian Irrigation Plan (1995-2008) and with resources from the Spanish national government. This plan prioritised the modernisation of irrigation techniques in order to both enhance farms' competitiveness and to ensure the sustainability of 
farmers' incomes. Through the plan, $43 \%$ of the existing irrigation systems were modernised in 1997, and water consumption by irrigated agriculture was reduced by $435 \mathrm{hm}^{3}$ per year, a figure that exceeded forecasts made when the plan was being developed [10,11]. The Irrigation Agenda H-2015 for Andalusia aimed to complete the work begun with the previous plan, by modernising more than 396,000 hectares of irrigated land and achieving expected water savings of about $352 \mathrm{hm}^{3}$ per year. The investment for Andalusia (where the Guadalquivir RB accounts for $85 \%$ of the total irrigated area) was estimated at 1.54 billion EUR (of which $59 \%$ was publicly subsidised) for 347,234 ha (representing an average investment of $4438 \mathrm{EUR} / \mathrm{ha}$ ) in the analysed period [12]. According to Corominas and Cuevas [12], water efficiency (defined as the amount of water productively used divided by the total water supply) in the modernised areas in the Guadalquivir RB has risen from 0.67 to 0.84 . Among the more widespread initiatives in this modernisation process, the most important measures are the modification of irrigation networks by the implementation of drip irrigation systems, the construction of small 'in-farm' reservoirs to regulate water use, and the implementation of volumetric metering and water consumption control systems. Similarly, many irrigated olive groves have incorporated pumping stations and filtration systems (which are essential to drip irrigation systems), along with automated irrigation systems [13].

The intense modernisation process in the Guadalquivir RB is reflected in the continuous increase in the surface area of drip-irrigated land in the basin (Table 1). It is currently the primary irrigation method in the RB as it is employed in $66 \%$ of the total irrigated area, up from $12 \%$ in 1989 . The comparison at a national level highlights the intense process of modernisation that has taken place in the Guadalquivir $\mathrm{RB}$, which is well ahead of the rest of Spain in this regard. We would argue that the greater degree of mechanisation and modernisation achieved in the Guadalquivir RB is reflective of the high level of agronomic development reached, and is typical of closed RBs.

Table 1. Irrigation techniques in the Guadalquivir river basin (RB).

\begin{tabular}{cccccc}
\hline & $\mathbf{1 9 8 9}^{\mathbf{1}}$ & $\mathbf{1 9 9 9}^{\mathbf{2}}$ & $\mathbf{2 0 0 2}^{\mathbf{2}}$ & $\mathbf{2 0 0 4}^{\mathbf{2}}$ & $\mathbf{2 0 0 8}^{\mathbf{3}}$ \\
\hline Gravity & $61 \%$ & $45 \%$ & $40 \%$ & $38 \%$ & $22 \%$ \\
Sprinkler & $27 \%$ & $20 \%$ & $22 \%$ & $17 \%$ & $12 \%$ \\
Drip & $12 \%$ & $35 \%$ & $38 \%$ & $45 \%$ & $66 \%$ \\
\hline \multicolumn{7}{l}{ Notes: Source: ${ }^{1}$ Agricultural census; ${ }^{2}$ Irrigation registry; ${ }^{3}$ Hydrological RB plan [8]. }
\end{tabular}

The substantial investments made as part of the intense modernisation process in the basin have also resulted in an increase in water costs in both nominal and real terms, due mainly to the higher energy-use intensity of drip and sprinkler irrigation techniques and having to resort to deeper or more distant sources (Table 2). Broken down by type of crops, the highly technical irrigated olive groves, mostly concentrated in the upper basin area, register an average cost of $0.15 \mathrm{EUR} / \mathrm{m}^{3}$, while extensive and semi-intensive irrigation crops in the mid-basin and lower basin area enjoy lower costs of $0.03 \mathrm{EUR} / \mathrm{m}^{3}$ for surface water and $0.06 \mathrm{EUR} / \mathrm{m}^{3}$ for groundwater [11].

Table 2. Average water cost by source $\left(\mathrm{EUR} / \mathrm{m}^{3}\right)$.

\begin{tabular}{ccccc}
\hline & \multicolumn{2}{c}{ Year } & \multicolumn{2}{c}{ Increase 2008 vs. 1997 } \\
\hline & $\mathbf{1 9 9 7}$ & $\mathbf{2 0 0 8}$ & Nominal & Real \\
\hline Surface & 0.04 & 0.06 & $47 \%$ & $10 \%$ \\
Ground & 0.09 & 0.14 & $52 \%$ & $15 \%$ \\
Regenerated & - & 0.21 & - & - \\
\hline
\end{tabular}

Notes: Source: Andalusia's Council of Agriculture and Fisheries [11].

The greater water use efficiency due to the modernisation of irrigation along with the observed water cost increases has led to significant changes in the composition of major crops cultivated in the basin. Besides the public/private response to water scarcity in terms of investing in WCTs and 
modernisation, farmers have tended to respond by dedicating more land to high value-added crops that use irrigation water more efficiently, with olive and citrus crops being notable examples.

Though there is limited information on the changes in yield of the different crops in the specific case of the Guadalquivir RB, a report from Castillo et al. [14] indicates that the increase in physical yields in modernised areas is similar to the regional average. A reason for this might be that pre-modernisation irrigation schemes were already highly productive and water distribution systems were in an acceptable state. The situation in the Guadalquivir RB is different to that in other Spanish basins such as the Ebro RB, where Lecina et al. [15] found an increase in productivity of about $28 \%$ after modernisation. Nevertheless, Castillo et al. [14] did find an increase in value added per hectare in the modernised areas due to changes in crops after the modernisation.

For our case study, Table 3 shows the changes that have occurred in the agriculture of the basin in recent years. The area occupied by olive and citrus crops has registered a considerable increase, while other irrigated crops such as cotton, corn and sugar beet report a significantly reduced presence in the basin. In parallel, the average irrigation water application in the basin fell by approximately $600 \mathrm{~m}^{3} / \mathrm{ha}$ between 2005 and 2012, which affected most of the crops but had a particularly notable impact on traditional olive groves, where the use of DI techniques is more widespread [16]. Table 3 also shows the annual relative irrigation supply (ARIS), i.e., the ratio of water applied to water required, for major crops in the basin; the figures reveal an overall reduction in these ratios for most crops. Data were not available for years prior to the study period, but taking into account the fact that pre-drought (1992-1994) average irrigation endowments amounted to $9500 \mathrm{~m}^{3} /$ ha, we can safely assume that in the early 1990s, endowments covered more than $100 \%$ of irrigation needs in the basin. The extent of DI techniques, especially in the case of olive groves (ARIS 0.41 and 0.61 for traditional and intensive olive crops, respectively), explain the high productivity associated with irrigation in the Guadalquivir RB. Furthermore, and as discussed in the next section, these high levels of productivity could not have been achieved without the water-use efficiency gains delivered by the extensive modernisation of irrigation technology observed in the basin.

Table 3. Irrigation rights and annual relative irrigation supply (ARIS) ratios for major crops in the Guadalquivir basin (2005-2012).

\begin{tabular}{lcccccc}
\hline \multirow{2}{*}{ Major Crops } & \multicolumn{2}{c}{ Irrigated Area (ha) } & \multicolumn{2}{c}{ Water Rights $\left.\mathbf{( m}^{\mathbf{3}} / \mathbf{h a}\right)$} & \multicolumn{2}{c}{ ARIS Ratio } \\
\cline { 2 - 7 } & $\mathbf{2 0 0 5}$ & $\mathbf{2 0 1 2}$ & $\mathbf{2 0 0 5}$ & $\mathbf{2 0 1 2}$ & $\mathbf{2 0 0 5}$ & $\mathbf{2 0 1 2}$ \\
\hline Traditional olive groves & 380,930 & 393,277 & 2281 & 1500 & 0.62 & 0.41 \\
Intensive olive groves & - & 76,323 & - & 2250 & - & 0.61 \\
Cotton & 77,020 & 55,302 & 6048 & 5600 & 0.7 & 0.65 \\
Cereals & 58,427 & 67,208 & 1500 & 2300 & 0.37 & 0.57 \\
Vegetables & 49,886 & 51,470 & 6104 & 5500 & 1.03 & 0.93 \\
Corn & 46,404 & 17,668 & 6624 & 6250 & 0.75 & 0.7 \\
Fruit trees & 24,795 & 23,927 & 5386 & 6000 & 1.39 & 1.55 \\
Citrus trees & 22,578 & 38,013 & 5501 & 5500 & 1.13 & 1.13 \\
Sugar beet & 20,185 & 12,230 & 3730 & 4500 & 0.55 & 0.67 \\
Sunflower & 18,032 & 23,251 & 1500 & 3200 & 0.31 & 0.66 \\
Rice & 36,092 & 35,180 & 14,000 & 13,000 & 1.06 & 0.99 \\
Weighted average $\mathrm{m}^{3} / \mathrm{ha}$ & - & - & 3949 & 3392 & 0.7 & 0.66 \\
\hline
\end{tabular}

Notes: Source: Own elaboration based on data from the Spanish Ministry of Agriculture, Food and Environment [7] and Confederación Hidrográfica del Guadalquivir [8].

According to the last two Guadalquivir Hydrological Plans (2009 and 2015), there is no possibility of a significant increase in water supply. A few minor reservoirs are under study but they are only projected to increase their present capacity by $4 \%$ (if the proposed increases are eventually approved subject to environmental, technical and economic considerations). Most groundwater reservoirs are under policy control and are designated 'fully exploited'; therefore, according to the hydrological plans that regulate water use, there is no prospect of additional significant resources and the basin is therefore in a 'closure' situation. 
Following the discussion of the main public and private responses to the progressive depletion of the water resource in the basin, the next section analyses the short- and long-term economic consequences of these responses on irrigation water productivity.

\section{Impacts on Irrigation Water Productivity}

Improving water efficiency seems to have been the main public and private institutional response to water scarcity in the Guadalquivir RB since the administrative moratorium in 2005. Although the modernisation process started slowly after the severe drought in the period 1992-1995 [17], the most intensive period of activity began around 2005, when the largest water user associations (WUA) started the process of upgrading their irrigation infrastructure [18]. As WCTs boost the water productivity ratio by both increasing the numerator (higher value added in the crop plan) and reducing the denominator (lower water use), they help create a dynamic process of productivity improvement (Figure 2).

This basin closure process is illustrated in Figure 2. As WCTs increase irrigation water productivity, the expansion of new irrigated areas consequently leads to increasing pressures on the resource and the basin. As Berbel and Mateos [19] and Playán and Mateos [20] state, there is no significant increase in water consumption when WCT investments are accompanied by strict control on the part of the water authority through a moratorium on irrigation expansion. Such control helps prevent situations where savings in water abstraction result in additional water depletion due to the water saved being used in new irrigated areas. In our case study, the Guadalquivir Water Authority has only been partially successful in reducing the growth in irrigated areas, given that the annual growth rate of irrigated areas has decreased from $9 \%$ to $0.8 \%$ after basin closure in 2005 (Table 4). Nevertheless, since the main modernisation process began in 2005, this process cannot be seen as the cause of irrigation expansion in the case of the Guadalquivir basin.

In parallel, the extensive modernisation of irrigation systems has enabled widespread use of DI (as shown in Table 3). DI techniques, as well as the higher efficiency levels achieved in the use of irrigation water due to WCTs, have led to a remarkable increase in the economic productivity of irrigated agriculture. This in turn affects the characteristics of water demand by reducing the elasticity of demand with respect to the increasing water prices [21]. In this scenario dominated by increasing pressures on water demand and a growing scarcity of the resource, the Guadalquivir RB has reached a state of closure, with no additional water resources to be consumed.

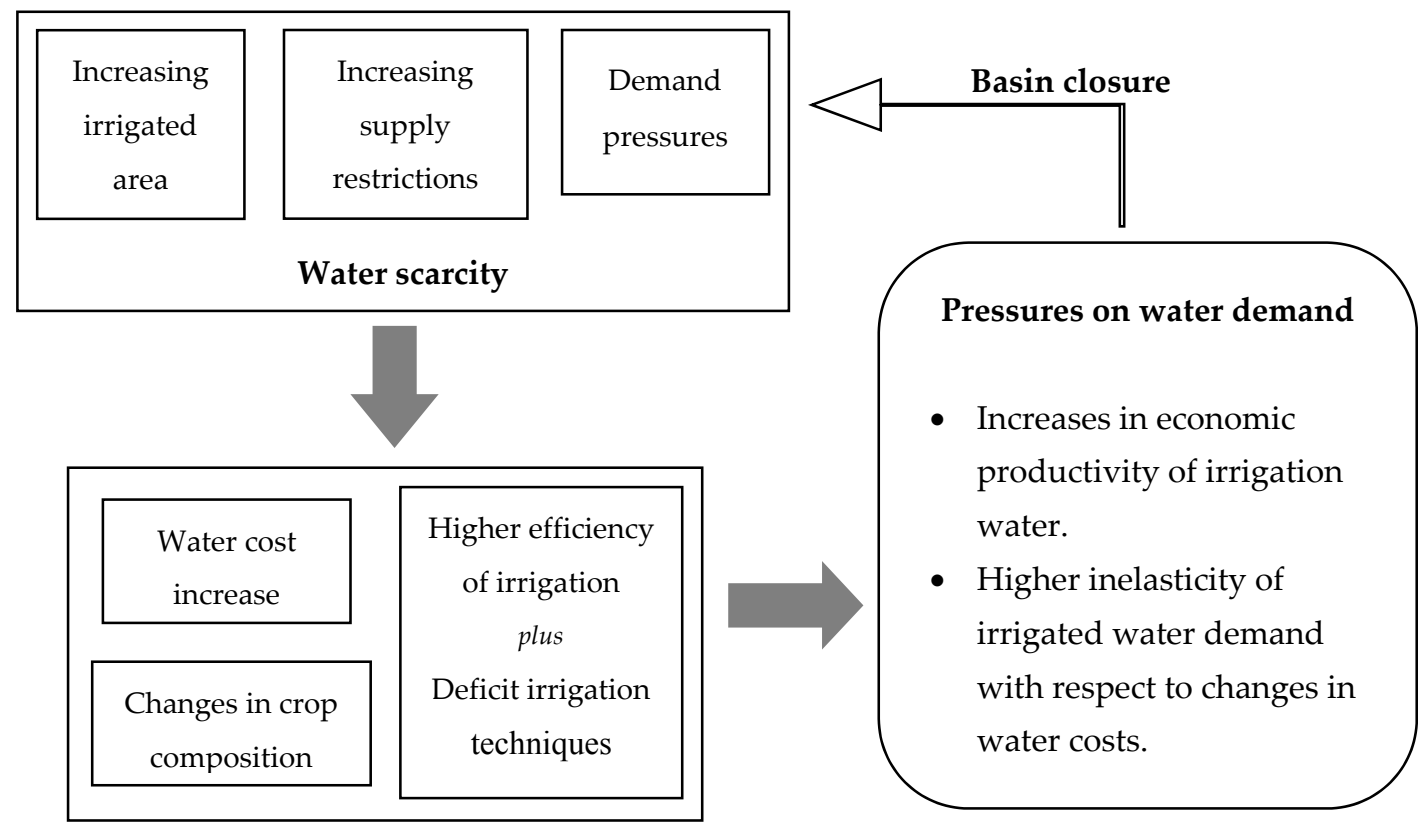

Figure 2. Model of a basin closure process. (Adapted from Berbel et al. [18]). 
With respect to DI and new crops, Expósito and Berbel [16] study a sample of olive farmers in the Guadalquivir RB and conclude that the model that best explains their behavior centers on the maximisation of the value of the marginal product of water, considering it to be the true limiting factor of production. This is contrary to traditional theory that considers land as the limiting factor. The rationale of maximising the productivity of a scarce factor (water) can be observed in the Guadalquivir RB, where farmers generally opt for DI techniques and high-tech irrigation for high value crops, in order to maximise the productivity of all production factors: water, land, labor and capital.

As a result, irrigation water productivity has increased dramatically in the Guadalquivir RB in recent decades. Table 4 shows the yields obtained by rain-fed and irrigated agriculture in terms of the gross value added (GVA) in the Guadalquivir RB. Data for 1989 and 2005 are obtained from the estimates made by Carrasco et al. [22], and these are supplemented with our own estimates for 2012. GVA measures have been estimated based on data for prices, crop yields, subsidies and direct costs, all of which have been sourced from the Agricultural and Fisheries Statistics of Andalusia, the Prices and Markets Observatory of Andalusia's Council of Agriculture and Fisheries (CAP), as well as the Survey of Crops and Agricultural Incomes from the Spanish Ministry of Agriculture, Food and Environment (MAGRAMA).

Following Carrasco et al. [22], we assume that the increase in the economic productivity of irrigated agriculture due to improvements in labor and capital factors (e.g., improved seeds, machinery, etc.) is incorporated in the productivity of land and estimated by the increase over rain-fed farming productivity. Therefore, mean irrigation water productivity may be estimated as the difference between the estimated economic productivity (in terms of GVA generated per hectare) of irrigated agriculture and that of rain-fed farming. As argued by Carrasco et al. [22], it seems clear that this assumption represents an important limitation, as resulting estimates would be valid only if the sole difference between rain-fed and irrigated agriculture were the amount of water used. In practice, however, it is clear that other differentiating factors, such as the use intensity of physical and human capital involved in crop cultivation, play a relevant role in explaining productivity differences. However, bearing in mind the limitations of this simplification, the estimates presented in Table 4 show the analysis of the main variables related to irrigation and the estimated evolution of mean productivity associated exclusively with irrigation water.

Table 4. Irrigation water mean productivity in the Guadalquivir RB. GVA: gross value added.

\begin{tabular}{|c|c|c|c|c|c|}
\hline \multirow{2}{*}{ Indicator } & \multicolumn{5}{|c|}{ Annual Increase Rate } \\
\hline & 1989 & 2005 & 2012 & 1989-2005 & 2006-2012 \\
\hline [1] GVA of irrigation farming (EUR/ha) & 1579 & 2653 & 2660 & $4.00 \%$ & $0.10 \%$ \\
\hline [2] GVA of rain-fed farming (EUR/ha) & 416 & 598 & 659 & $2.60 \%$ & $1.40 \%$ \\
\hline $\begin{array}{l}\text { [3] Increase in productivity due to irrigation } \\
{[3]=[2]-[1](\text { EUR } / \text { ha) }}\end{array}$ & 1163 & 2055 & 2001 & $\mathrm{n} / \mathrm{a}$ & $\mathrm{n} / \mathrm{a}$ \\
\hline [4] Average irrigation water application $\left(\mathrm{m}^{3} / \mathrm{ha}\right)$ & 9995 & 4137 & 3392 & $-3.40 \%$ & $-2.60 \%$ \\
\hline $\begin{array}{l}\text { [5] Irrigation water mean productivity } \\
{[5]=[3] /[4]\left(E U R / \mathrm{m}^{3}\right)}\end{array}$ & 0.116 & 0.497 & 0.603 & $19.30 \%$ & $3.00 \%$ \\
\hline [6] Irrigated area (ha) & 316,646 & 801,865 & 845,986 & $9.00 \%$ & $0.80 \%$ \\
\hline [7] Rain-fed area (ha) & $2,412,091$ & $2,128,952$ & $1,950,853$ & $\mathrm{n} / \mathrm{a}$ & $\mathrm{n} / \mathrm{a}$ \\
\hline
\end{tabular}

Results show how the irrigation water mean productivity has increased from $0.11 \mathrm{EUR} / \mathrm{m}^{3}$ in 1995 to $0.60 \mathrm{EUR} / \mathrm{m}^{3}$ in 2012 , a cumulative increase of $425 \%$. However, significant differences are observed between the two analysed periods, 1995-2005 and 2006-2012. In the period 1995-2005, a remarkable expansion of irrigated area occurs in the Guadalquivir RB, with a $153 \%$ increase recorded (mainly in woody crops such as citrus and olive groves, which represent about $60 \%$ of the total increase in 
irrigated area in the RB). This expansion of irrigated areas in the basin, along with a $60 \%$ reduction in water consumption per hectare as a result of the modernisation of irrigation techniques, explains the significant increase in the irrigation water mean productivity in the period 1995-2005, rising from 0.11 to $0.49 \mathrm{EUR} / \mathrm{m}^{3}$ ( $345 \%$ increase).

During the period 2006-2012, the average water consumption per hectare decreases by $20 \%$, to approximately $3400 \mathrm{~m}^{3} / \mathrm{ha}$, while the capacity of irrigated agriculture to generate greater GVA levels than rain-fed agriculture remains largely unchanged (2001 EUR/ha. in 2012 compared to 2055 EUR/ha. in 2005). In our opinion, this would seem to indicate that the observed increase in the irrigation water mean productivity (from 0.49 to $0.60 \mathrm{EUR} / \mathrm{m}^{3}$ ) in this period can be explained almost exclusively by the higher production efficiency of irrigated farming, which is thus able to generate the same yield levels with lower levels of water consumption.

In this regard, the capacity of the Guadalquivir RB to increase GVA through irrigation tends to level out in terms of GVA per irrigation unit. As a result of the marked expansion of irrigation agriculture in the basin, water resources have become the limiting production factor, in contrast with the traditional model that defines land as the limiting factor. Since the degree of modernisation and efficiency of irrigation techniques in the Guadalquivir RB is already high, the ability of irrigated farming to continue generating greater GVA declines, a situation which characterises the current closure of the basin. Figure 3 highlights this process by showing the evolution of indexes constructed for the GVA of irrigated farming, consumption of irrigation water and irrigation rights in the period 1989-2012, taking 1989 as the base year $(1989=100)$.

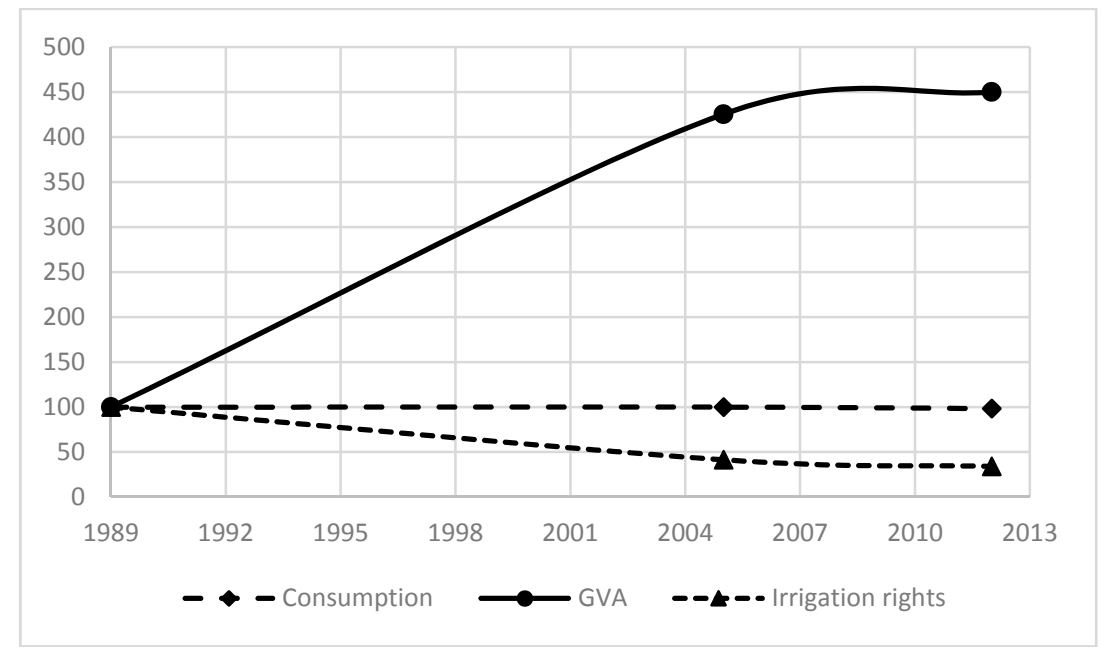

Figure 3. Indexes of water consumption, irrigation rights and GVA. Note: Base year $1989=100$.

The water mean productivity of major crops in the Guadalquivir RB is quite heterogeneous. Table 5 shows the 2012 data on GVA per hectare for major irrigated and rain-fed crops, obtained by applying a similar method to that used previously to estimate irrigation water productivity in the basin (Table 4). Estimates show that the highest GVA-to-irrigation water ratio is achieved by olive and citrus crops. These crops have registered the largest increase in cultivated area over the analysed period, accounting nowadays for more than $60 \%$ of total irrigated area in the Guadalquivir RB. According to Castillo et al. [14], prices of major crops in the Guadalquivir RB have decreased in real terms in the last two decades, and this reduction in price has not been fully offset by the increase in physical production, meaning that income per hectare has decreased in real terms. Farmers have reacted to this situation by switching from commodity crops (i.e., cereals, sugar beet, cotton) to higher value crops (i.e., citrus, olive).

Thus, the increase in the area dedicated to the cultivation of high-productivy irrigated crops observed in recent years could be explained by their higher GVA-to-irrigation water ratio compared to 
alternative crops. This increase adds to the pressure on the scarce water resources and reinforces the basin closure cycle.

The analysis of our case study has clearly revealed how greater resource-use efficiency has led to the expansion of irrigated areas of those crops with higher levels of GVA per irrigation unit (i.e., olive and citrus crops). In our opinion, the declining capacity of irrigated farming in the basin to generate greater GVA per hectare, as shown by the slowing rate of average annual increase in irrigation water mean productivity in the period 2005-2012, would explain the present situation in the Guadalquivir RB. This slow-down in productivity gains reflects the diminishing returns to scale of technical innovation, with DI, crop change and irrigation modernisation reaching the limits of their capacity to create new value, which in turn means that the economic productivity of irrigation water in the basin reaches a plateau.

Table 5. Productivity of rain-fed and irrigated crops in the Guadalquivir RB, 2012.

\begin{tabular}{|c|c|c|c|c|c|}
\hline & Type of Crop & & $\begin{array}{l}\text { (1) Crop GVA/ha } \\
\text { (EUR/ha) }\end{array}$ & $\begin{array}{l}\text { (2) Irrigation Rights } \\
\left(\mathrm{m}^{3} / \mathrm{ha}\right)\end{array}$ & $\begin{array}{c}(1) /(2) \\
\text { GVA/Irrigation } \\
\left(\text { EUR/m } \mathrm{m}^{3}\right)\end{array}$ \\
\hline \multirow{3}{*}{ Cereals } & Wheat & rain-fed & 431 & - & - \\
\hline & Rice & irrigated & 2451 & 13,000 & 0.19 \\
\hline & Corn & irrigated & 2768 & 6250 & 0.44 \\
\hline \multirow{3}{*}{ Industrial } & Sunflower & rain-fed & 471 & - & - \\
\hline & Cotton & irrigated & 1155 & 5600 & 0.21 \\
\hline & Sugar beet & irrigated & 2726 & 4500 & 0.61 \\
\hline Citrus & Oranges & irrigated & 6300 & 5500 & 1.15 \\
\hline \multirow{4}{*}{ Olive groves } & Table olives & rain-fed & 1426 & - & - \\
\hline & Oil-mill olives & rain-fed & 1302 & - & - \\
\hline & Table olives & irrigated & 1755 & 1500 & 1.17 \\
\hline & Oil-mill olives & irrigated & 2500 & $1500-2250$ & $1.11-1.67$ \\
\hline
\end{tabular}

Note: Source: Own elaboration.

\section{Discussion}

This paper illustrates recent trends in agricultural irrigation water use and changes in crop choices and yields in the Guadalquivir RB over the last two decades. Findings show that these factors have led to a substantial increase in irrigation water productivity and total resource allocation, which are typical characteristics of a highly developed and closed river basin [23]. The evolution of water supply costs shows an upward trend characteristic of a mature water economy, according to Randall [3]. Farmers have chosen techniques and crops that maximise water productivity, since water is the most limiting factor. As we have described in our analysis, the factors driving irrigation water productivity in the Guadalquivir RB are multidimensional by nature:

1) Economic dimension.

a) Change in crop patterns towards a preponderance of more productive crops.

2) Technical dimension.

b) Increase in conveyance efficiency (distribution channels).

c) Water-saving techniques (mainly drip irrigation and high-tech systems).

3) Agronomic dimension.

d) Implementation of deficit irrigation (DI).

4) Institutional dimension.

e) Reduction in water rights allocation. 
The first three responses (crop pattern change, improved conveyance efficiency and water-saving techniques at farm level) are well documented (e.g., Molden et al. [24]; Molle et al. [25]). However, the last two responses (extensive use of DI techniques and reduction in water rights allocation) are distinctive features of the Guadalquivir RB and the published evidence on them is scarce; our analysis of these features can therefore be considered one of the main contributions of our analysis.

Randall [3] describes the economic consequence of this technical change in the mature water economy phase as a high and growing demand for delivered water, which is elastic at low prices and inelastic at high prices. When water supply is constrained, farmers reallocate scarce water resources in an attempt to maximise the marginal product value of water. This strategy may be implemented in a number of ways: (a) 'inside the farm' (when farmers switch to higher value crops or invest in WCT and water-saving strategies such as DI), (b) through the sale of land (which generally includes water rights) from one farmer to another and (c) by selling water rights independently of land. The trade in water rights has been legal in Spain since 2005, although the practice is very limited. Berbel and Mesa [26] describe a case study in the Guadalquivir RB where the water allocated to rice fields was sold to a consortium of greenhouse growers (a transfer from low value to high value uses).

The current irrigation paradigm sees drip irrigation as a more rational and efficient means of using water, with the expansion of drip irrigation advocated as a way of improving water and farm productivity. Huge increases in water productivity are attributed to this technique, for example "shifting from conventional area irrigation to drip irrigation in India has increased overall water productivity by $42 \%-255 \%$ for crops" [27]. Moreover, Molden et al. [24] indicate that increases in water productivity at the farm level can increase basin water depletion, especially where water is scarce compared with land resources, which may well be the case with the Guadalquivir RB.

Irrigation system modernisation is frequently supported by public subsidies, as is the case in Spain as well as some western US states such as California [28], where public subsidies have supported WCTs as part of the measures to fight the drought that has afflicted the western United States since 2010. Some authors criticise drip irrigation, including Van der Kooij [29], who provides a review of the literature on the impacts of drip irrigation and concludes that there is no conclusive scientific evidence to support the general belief in drip irrigation as a water-saving device or as a tool to help solve the water crisis. Along the same lines, Batchelor et al. [30] state that WCTs often contribute to an intensification of water use. Also, conveyance infrastructure improvement may create additional pressures in terms of water depletion, as Playán and Mateos [20] and Lecina et al. [15] have illustrated in the case of WUA modernisation in northern Spain.

This critical assessment of WCT investment is also reflected in the views of a number of academics and water policy-makers; for example, the European Commission warns of the possibility of a 'rebound effect' in water-stressed regions investing in the modernisation of their irrigation networks [31]. In our case study, the recent evolution of the Guadalquivir RB shows that the expansion in irrigated areas (mainly olive groves cultivated with DI techniques in the period 1989-2005) preceded the modernisation process (which began around 2005). It is our belief, therefore, that the progression of resource depletion in the Guadalquivir RB is not an example of the rebound effect, given that the depletion began before the modernisation process got underway. The question is, does the modernisation of the irrigation system exacerbate resource depletion? As shown by Berbel and Mateos [19], the existence of the rebound effect depends on the initial state of the agricultural system, although the main determining factor is the water authority's acceptance of an expansion of irrigated areas.

Nevertheless, the policy of investing in water supply enhancement rather than WCTs is not in fact contradictory, as it is frequently depicted in the literature. In this regard, the analysis of Xie and Zilberman [32] supports the argument that both water efficiency subsidies and policies to increase the water supply can be complementary approaches to achieving water sustainability objectives.

We believe that there is no inherent contradiction in these two approaches, as they are based on different performance measures. More optimistic authors define performance as water value divided 
by water used (abstracted), whereas the pessimistic view takes a global basin perspective and considers water consumption (evapotranspiration, ETP) as the critical variable. In this regard, Berbel et al. [33] provide a critical review of the published scientific evidence on the impact of water-saving investment on water use (abstraction) and water consumption (mainly ETP).

In our research, we have focused on water abstraction and irrigation rights as the variable that is determined by the water authority, and propose standard performance measures estimated as the ratio of GVA of irrigated area minus GVA of rain-fed area divided by irrigation water use (abstraction). We thus avoid the complexities of using water consumption in the denominator, as this requires ETP estimations and the analysis of the global basin water accounts, which fall outside the scope of this paper. An analysis of water productivity based on a hydrological model where consumption (or ETP) and reuse of irrigation water returns are obtained through the development a global basin water balance in accordance with System of Economic Environmental Accounts-Water methodology, can be seen in Borrego-Marín et al. [34], which estimates an average gross water productivity for irrigation of $1.33 \mathrm{EUR} / \mathrm{m}^{3}$ in the period 2004-2012.

As we have previously mentioned, a distinctive feature of the Guadalquivir RB, besides the higher water-use efficiency due to modern irrigation techniques, is the widespread adoption of DI practices, especially among olive farmers [16]. This trend, which was initially observed in olive groves, is now extending to other Mediterranean crops such as almonds, which have begun to use DI techniques as they replace other less productive herbaceous and woody crops.

The aggregate basin-level consequences of the individual farmer behavior seeking to maximise water productivity is greater pressure on water resources fueled by the increased water productivity. Thus, growth in the economic productivity of irrigated land well above that of rain-fed land ( $4 \%$ per irrigated hectare compared to $2.5 \%$ per rain-fed hectare in the period 1989-2005) has encouraged the expansion of crops that produce higher yields per unit of irrigation (i.e., olive and citrus crops), thus increasing water demand and consuming the water savings achieved through the use of more efficient irrigation techniques.

Since the current Guadalquivir Hydrological Plan 2015-2021 only contemplates small increases of irrigable area in the basin (a supply expansion of just $20 \mathrm{hm}^{3}$ is planned, sourced from reused treated urban wastewater), we believe that the use of instruments to achieve greater flexibility in the allocation of water resources in the basin is needed. In this regard, the development of a water rights market would be helpful; in the specific context of the Guadalquivir RB it could help alleviate the increasing pressures on the resource [35]. Thus, farmers' demands for increased irrigation capacity of the basin could be met by transferring irrigation rights from less productive to more productive farms. One consequence of this water trade will be an additional increase in water productivity as water moves from lesser to higher value crops, but this factor cannot yet be included in the analysis because water markets are still not fully operational in the basin.

On the demand side and in the context of our case study, we believe that raising the price of irrigation water would not have a significant effect in terms of water consumption reductions [21]. Moreover, in situations where cost recovery of water services is already at acceptable levels (the Guadalquivir RB has a recovery rate of around $86 \%$ ) [35], raising the costs of irrigation water would not be enough to significantly reduce water demand. In our opinion, water pricing alone is not an effective means of supporting improvements in the status of water bodies (in line with the environmental objectives of the European Water Framework Directive), although other public policy considerations, such as the prevention of cross-subsidisation between social groups or sectors, may justify price increases. However, such a debate touches on matters of a socio-political nature, which are clearly beyond the scope of this paper.

\section{Concluding Remarks}

Since 2005, the main policy measure used in the Guadalquivir RB has been aimed at modernising irrigated agriculture through the use of WCTs. The analysis carried out in this paper has shown a 
significant increase in mean irrigation water productivity in an initial period (1989-2005) driven by the creation of new irrigated areas devoted to high value crops and with a dominant use of deficit irrigation strategies. A subsequent phase (2005-2012), however, has been characterised by slower growth in terms of irrigation water mean productivity, primarily as a result of a significant reduction in water use per area.

Furthermore, the intense growth of irrigated agriculture in the Guadalquivir basin during recent decades has concentrated on crops with high yields per unit of water consumed, exacerbating demand pressures on the scarce water resources in the basin. As a result, the reduced hydrological capacity of the basin to meet human needs (especially agriculture) has led to its closure. We believe such a situation is typical of a basin that has achieved a high level of agronomic development by concentrating its agricultural production on crops capable of generating high economic returns in the face of a chronic shortage of water resources. In our opinion, Guadalquivir can be defined as a closed basin as almost all the water resources are allocated to farmers and other economic and environmental uses. Additional consumption demands-resulting from the increasing efficiency of irrigation techniques and the widespread use of DI practices with high-productivity crops (i.e., olive, citrus, and almond crops) - will continue to intensify the pressures in the basin. In this context, the water authority needs to enforce policy control and ensure good governance to prevent additional consumption demands that cannot be met with the already depleted resources.

In future studies, we plan to expand the microeconomic analysis of the closure process of river basins by extending the study to other basins with different hydrological and environmental characteristics. Such an analysis would allow us to produce more robust results regarding the evolution of irrigation water productivity at a global basin level, as well as in major crops of the basin. We hope that this paper opens up new avenues for research in the field of water policy and encourages further study of the role of increasing water productivity in the evolution of a river basin.

Acknowledgments: This research has been financed by the Secretaría General de Ciencia, Tecnología e Innovación (MINECOAGL2014-53417-R).

Author Contributions: The authors contributed equally to this work.

Conflicts of Interest: The authors declare no conflict of interest.

\section{Abbreviations}

The following abbreviations are used in this manuscript:

$\begin{array}{ll}\text { ARIS } & \text { Annual Relative Irrigation Supply. } \\ \text { DI } & \text { Deficit Irrigation. } \\ \text { ETP } & \text { Evapotranspiration. } \\ \text { GVA } & \text { Gross Value Added. } \\ \text { RB } & \text { River Basin. } \\ \text { WCTs } & \text { Water-Saving and Conservation Technologies. } \\ \text { WUA } & \text { Water User Association. }\end{array}$

\section{References}

1. Ministerio de Medio Ambiente, Medio Rural y Marino (MARM). Estrategia Nacional para la Modernización Sostenible de los Regadíos H2015; Ministerio de Medio Ambiente, Medio Rural y Marino, Gobierno de España: Madrid, Spain, 2010.

2. Molle, F.; Wester, P.; Hirsch, P. River basin closure: Processes, implications and responses. Agric. Water Manag. 2010, 97, 569-577. [CrossRef]

3. Randall, A. Property entitlements and pricing policies for a maturing water economy. Aust. J. Agric. Econ. 1981, 25, 195-220. [CrossRef]

4. Comair, G.F.; Gupta, P.; Ingenloff, C.; Shin, G.; McKinney, D.C. Water resources management in the Jordan River Basin. Water Environ. J. 2013, 27, 495-504. [CrossRef] 
5. Venot, J.P.; Molle, F.; Courcier, R. Dealing with closed basins: The case of the Lower Jordan River Basin. Water Resour. Dev. 2008, 24, 247-263. [CrossRef]

6. Grantham, T.E.; Viers, J.H. 100 years of California's water rights system: Patterns, trends and uncertainty. Environ. Res. Lett. 2014, 9, 084012. [CrossRef]

7. Ministerio de Agricultura, Alimentación y Medio Ambiente (MAGRAMA). ESYRCE. Informe sobre Regadios en España; Ministerio de Agricultura, Alimentación y Medio Ambiente, Gobierno de España: Madrid, Spain, 2015.

8. Confederación Hidrográfica del Guadalquivir (CHG). Plan Hidrológico de la Demarcación del Guadalquivir 2015-2021; R. D. 1/2016; Confederación Hidrográfica del Guadalquivir: Sevilla, Spain, 2016.

9. Corominas, J. Los Nuevos Planes Hidrológicos de las Cuencas Andaluzas; Observatorio del Agua de la Fundación Botín: Madrid, Spain, 2010.

10. Consejería de Agricultura y Pesca (CAP). Inventario de Regadíos 2008 y Su Evolución en la Última Década; Consejería de Agricultura y Pesca, Junta de Andalucí: Sevilla, Spain, 2010.

11. Consejería de Agricultura y Pesca (CAP). Agenda del Regadio Andaluz H-2015; Consejería de Agricultura y Pesca, Junta de Andalucía: Sevilla, Spain, 2011.

12. Corominas, J.; Cuevas, R. Análisis crítico de la modernización de regadíos. In El Impacto de la Modernización de Regadíos en España; Berbel, J., Gutiérrez-Martín, C., Eds.; Cajamar Caja Rural: Almería, Spain, 2017; pp. 273-307.

13. Corominas, J. Análisis de las Modernizaciones de Regadios en Andalucía; Consejería de Agricultura y Pesca, Junta de Andalucía: Sevilla, Spain, 2011.

14. Castillo, M.; Borrego-Marín, M.M.; Berbel, J. Perspectiva del agricultor sobre el efecto de la modernización de regadíos en la distribución de cultivos. In El Impacto de la Modernización de Regadios en España; Berbel, J., Gutiérrez-Martín, C., Eds.; Cajamar Caja Rural: Almería, Spain, 2017; pp. 330-343.

15. Lecina, S.; Isidoro, D.; Playán, E.; Aragüés, R. Irrigation Modernization and Water Conservation in Spain: The Case of Riegos del Alto Aragón. Agric. Water Manag. 2010, 97, 1663-1675. [CrossRef]

16. Expósito, A.; Berbel, J. Microeconomics of Deficit Irrigation and Subjective Water Response Function for Intensive Olive Groves. Water 2016, 8, 254. [CrossRef]

17. Gómez-Limón, J.A. Implicaciones para la nueva planificación hidrológica para la agricultura de regadío. In La Economía del Agua de Riego en España, una Perspectiva Regional; Gómez-Limón, J.A., Calatrava, J., Garrido, A., Sáez, F.J., Xabadia, A., Eds.; Cajamar Caja Rural: Almería, Spain, 2009; pp. 33-54.

18. Berbel, J.; Kolberg, S.; Martin-Ortega, J. Assessment of the Draft Hydrological Basin Plan of the Guadalquivir River Basin (Spain). Int. J. Water Resour. Dev. 2012, 28, 43-55. [CrossRef]

19. Berbel, J.; Mateos, L. Does investment in irrigation technology necessarily generate rebound effects? A simulation analysis based on an agro-economic model. Agric. Syst. 2014, 128, 25-34. [CrossRef]

20. Playán, E.; Mateos, L. Modernization and optimization of irrigation systems to increase water productivity. Agric. Water Manag. 2006, 80, 100-116. [CrossRef]

21. Expósito, A.; Berbel, J. Why is water pricing ineffective for deficit irrigation schemes? A case study in southern Spain. Water Resour. Manag. 2016. [CrossRef]

22. Carrasco, J.M.; Pistón, J.M.; Berbel, J. Evolución de la productividad del agua en la Cuenca del Guadalquivir 1989-1995. Agric. Resour. Econ. 2010, 10, 57-67.

23. Berbel, J.; Pedraza, V.; Giannoccaro, G. The trajectory towards basin closure of a European river: Guadalquivir. Int. J. River Basin Manag. 2013, 11, 111-119. [CrossRef]

24. Molden, D.; Oweis, T.; Steduto, P.; Bindraban, P.; Hanjra, M.A.; Kijne, J. Improving agricultural water productivity: Between optimism and caution. Agr. Water Manag. 2010, 97, 528-535. [CrossRef]

25. Molle, F.; Wester, P.; Hirsch, P.; Jensen, J.R.; Murray-Rust, H.; Paranjpye, V.; Pollard, S.; Van der Zaag, P. River basin development and management. In Water for Food, Water for Life: A Comprehensive Assessment of Water Management in Agriculture; Molden, D., Ed.; Earthscan and Colombo, International Water Management Institute: London, UK, 2007; pp. 585-624.

26. Berbel, J.; Mesa, P. Valoración del agua de riego por el método de precios quasi-hedónicos: Aplicación al Guadalquivir. Economía Agraria y Recursos Naturales (Agric. Resour. Econ.) 2007, 14, 127-144.

27. Gleick, P.H. Water management: Soft water paths. Nature 2002, 418, 373. [CrossRef] [PubMed] 
28. Medellín-Azuara, J.; Howitt, R.; Harou, J. Predicting farmer responses to water pricing, rationing and subsidies assuming profit maximizing investment in irrigation technology. Agric. Water Manag. 2012, 108, 73-82. [CrossRef]

29. Van der Kooij, S. Performing Drip Irrigation by the Farmer Managed Seguia Khrichfa Irrigation System, Morocco; Wageningen University: Wageningen, The Netherlands, 2016.

30. Batchelor, C.; Reddy, V.R.; Linstead, C.; Dhar, M.; Roy, S.; May, R. Do water-saving technologies improve environmental flows? J. Hydrol. 2014, 518, 140-149. [CrossRef]

31. European Commission. A Blueprint to Safeguard Europe's Water Resources; European Commission (EC): Brussels, Belgium, 2012.

32. Xie, Y.; Zilberman, D. Water-Storage Capacities versus Water-Use Efficiency: Substitutes or Complements? In Proceedings of the 2015 AAEA \& WAEA Joint Annual Meeting, San Francisco, CA, USA, 26-28 July 2015.

33. Berbel, J.; Gutiérrez-Martín, C.; Rodríguez-Díaz, J.A.; Camacho, E.; Montesinos, P. Literature Review on Rebound Effect of Water Saving Measures and Analysis of a Spanish Case Study. Water Resour. Manag. 2015, 29, 663-678. [CrossRef]

34. Borrego-Marín, M.M.; Gutiérrez-Martín, C.; Berbel, J. Estimation of cost recovery ratio for water services based on the System of Environmental-Economic Accounting for Water. Water Resour. Manag. 2016, 30, 767-783. [CrossRef]

35. Berbel, J.; Gutiérrez-Martín, C.; Giannoccaro, G. Una visión realista de los mercados de derechos de agua. In Los Mercados de Agua en España: Presente y Perspectivas; Gómez-Limon, J.A., Calatrava, J., Eds.; Cajamar Caja Rural: Almeria, Spain, 2016; pp. 411-426.

(C) 2017 by the authors. Licensee MDPI, Basel, Switzerland. This article is an open access article distributed under the terms and conditions of the Creative Commons Attribution (CC BY) license (http:/ / creativecommons.org/licenses/by/4.0/). 